\title{
Chelated amino acids: biomass sources, preparation, properties, and biological activities
}

\author{
Rania H. Jacob ${ }^{1} \cdot$ Adel S. Afify $^{1} \cdot$ Sanaa M. Shanab ${ }^{2} \cdot$ Emad A. Shalaby $^{1}$
}

Received: 10 December 2021 / Revised: 10 January 2022 / Accepted: 11 January 2022

(c) The Author(s) 2022

\begin{abstract}
Micronutrients such as $\mathrm{Zn}, \mathrm{Cu}, \mathrm{Fe}$, and $\mathrm{Mn}$ are required metals for plant crops to increase their yield and quality. Metals are included in numerous biochemical reactions as enzymes, co-enzymes, and co-factors. Copper, zinc, and manganese are essential for the development and growth of animal as pigs and broiler chicks. Amino acids are of significant importance and are used in many applications, fields, and industries such as food, animal feed, supplement, pharmaceutical production, and as biofertilizers. Fertilizers of inorganic mineral structure are hardly diffused from the leaf surface into the plant, while chelated minerals with amino acids provide a great advantage in increasing the absorption efficiency and translocation of minerals within the plant.

Also, it was known that derivatives of free or chelated amino acids have marked antioxidant activity and are able to inhibit the development of tumor tissues and leading to increase immune protective abilities of the organisms. Nanotechnology increased the application efficiency of metal-amino acid complexes. Using nano fertilizers to plants is one of critical importance due to their unique properties in size and increased surface areas. It released the nutrients on demand and regulates plant growth (such as wheat, rice, barley, and rapeseed plants). Metal chelating complexes have found extensive applications in various fields of human interest.

Chelators are used in medical applications; water softeners are included as ingredients in many commercial products such as shampoos and food preservatives and control heavy metal pollution in aquacultures. Amino acids may be used separately in chelation process as free amino acids or can be separated from plant or animal wastes. It can be separated by hydrolysis of plant or agricultural crop wastes as thrones of tomato and sugar beet plants. Also, it can be separated from animal origin as leather wastes and chicken feather waste or from whey of cow milk after mozzarella cheese formation. So, amino acid production from wastes decreases the cost of metal-chelated complex formation.
\end{abstract}

Keywords Leather waste $\cdot$ Chelated amino acids $\cdot$ Biological actions $\cdot$ Preparation methods $\cdot$ Chemical and physical properties

\section{Introduction}

Animal and agriculture biomasses are highly abundant renewable sources that can be converted into different types of high-value-added products, including fertilizers, chemical compounds for soil reclamation, biofuels, and other advanced materials. In the last decades, an increasing

Emad A. Shalaby

emad.ahmed@agr.cu.edu.eg; dremad2009@yahoo.com

1 Department of Biochemistry, Faculty of Agriculture, Cairo University, Giza 12613, Egypt

2 Department of Botany and Microbiology, Faculty of Science, Cairo University, Giza 12613, Egypt amount of these biomasses and processing techniques have been developed to increase the biomass application followed by the industrial application of the products [1],Shanab et al., 2018). The main objective of the review is to focus on the use of the biomasses from different sources such as leather wastes, single-cell protein algae, and different agricultural wastes (Fig. 1) as amino acid source for chelation with trace minerals for more bioavailability in both forms (native and nano) and evaluation of the obtained products in plant nutrition arriving to the best ratio of the selected minerals (zinc, iron, manganese, magnesium, cupper, and others). Nanoparticles of selected minerals were prepared using different green synthesis approaches by the extracts from all mentioned unused biomasses. Value may be of great 
Fig. 1 The most biomass wastes rich with amino acid content

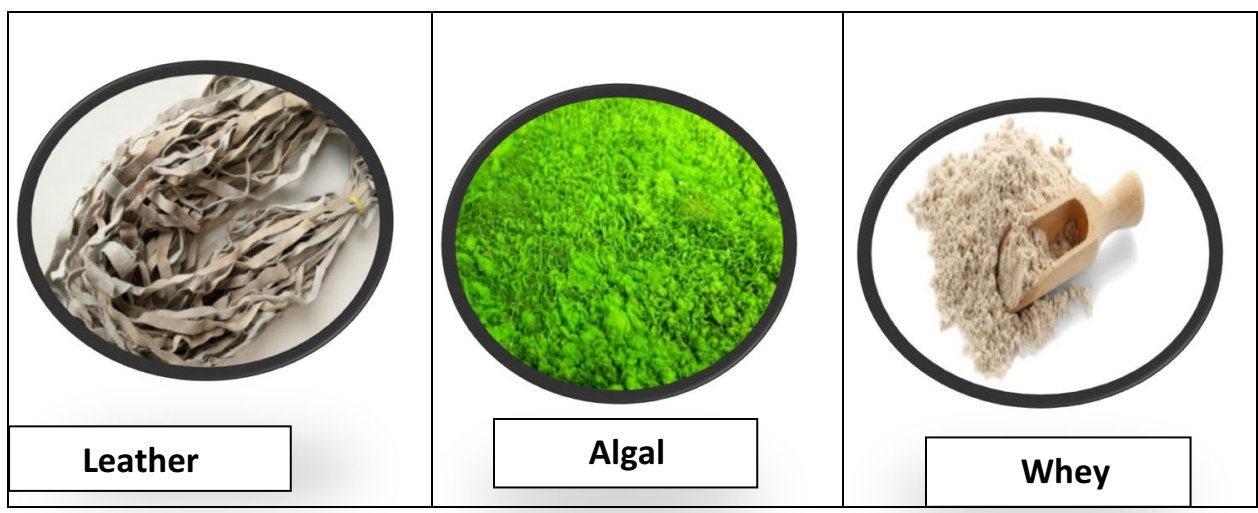

significance to plant nutrition in cost reduction of nutrition and improving performance; to nutritionists and nanotechnologists in validating new and innovative techniques in nutrition research; and to environmentalists in reducing accumulated industrial and agriculture pollutant wastes in the environment.

Animal skins have a major component of proteins (90-95\%). It is used to produce tanned leather. Collagen is the main protein found in hide and is used in many industries [2].

Leather tanning process produces huge amounts of different wastes (Fig. 2). These wastes include solid, liquid, and gases, which cause many environmental and economic problems in many countries. Liquid waste is the wastewater produced during tanning step and form sludge, while the gaseous waste is organic and inorganic that resulted from the breakdown of proteins [3]. Most of the solid wastes pollute the environment and the less harmful method for its removal is the recycling through heating treatments $[3,4]$.

Before discussing the methods for preparation and utilization of chelated amino acids, we will provide short notes or definition or key notes about some terms which used in this study as follows:

\subsection{Chelation}

Chelation is a chemical process of attaching organic molecule (natural or synthetic) to a mineral in two or more places to form a ring. The molecule surrounds and protects the mineral from any adverse interaction.

\subsection{Importance of chelation}

Micronutrients are mostly applied to plants by mixing with the soil or through foliar application to the plant leaves. Application of minerals ( $\mathrm{Fe}, \mathrm{Mn}, \mathrm{B}, \mathrm{Cu}$, or $\mathrm{Zn}$ ) as mineral salts is affected by the $\mathrm{pH}$ (acidic, neutral, or alkaline). It may be converted into insoluble forms leading to a marked decrease in their absorption.

Foliar spray fertilizers which have inorganic mineral are hardly diffused from the leaf surface into the plant due to its high molecular weight structure [5].

\subsection{Amino acid chelation}

Amino acids are the building units of proteins in all living organisms. Chelating amino acids with minerals led (Fig. 3)
Fig. 2 Different types of wastes produced from multiple stages of leather industry

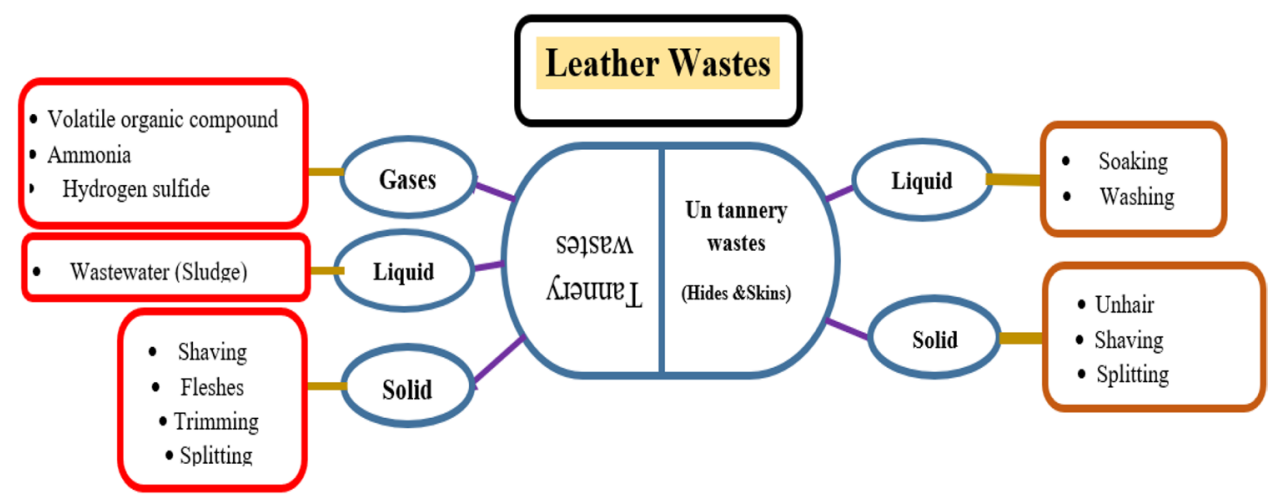


Fig. 3 Some chelated amino acid structures

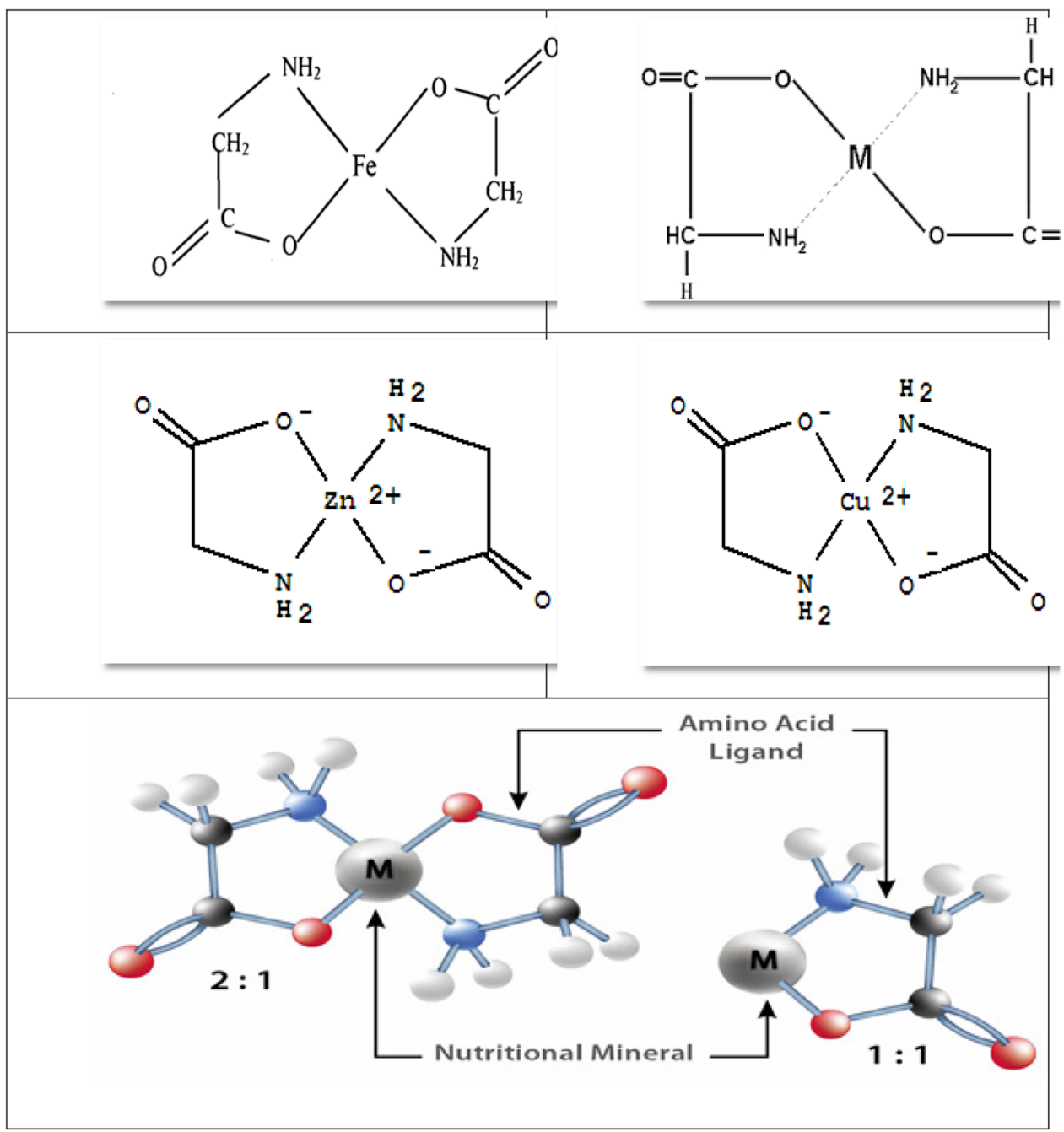

to a marked increase in absorption efficiency and translocation of minerals within the plant [6].

\subsection{Advantages of amino acid chelation with minerals}

The advantages are as follows: use of small amount, low cost, high rate of repay, and increase the output of crops as well as improve its quality. It may get rid or kill bacteria and insects and decrease the residual pesticide [5].

\subsection{Fields of applications}

Chelated minerals are largely used in medicine, poultry, and livestock industry and in agriculture as biofertilizers [7].

\section{Preparation of chelated amino acids (Fig. 4)}

Different methods for preparing minerals depending on hydrolysis of protein from different types of wastes (such as leather waste, chicken feather, or pig skin) and elements or using pure amino acids and elements [8].

The first or commercial method employed hydrolysate content of amino acids and elements in certain proportions. The best ratios used are 2:1, 2.5:1, and 3:1 using $5 \mathrm{~g}$ of chicken feather with $250 \mathrm{ml}$ of $6 \mathrm{M} \mathrm{H}_{2} \mathrm{SO}_{4}$ (for acidic hydrolysis) or $6 \mathrm{M} \mathrm{KOH}$ (for alkaline hydrolysis) and a catalyst $\left(1 \mathrm{ml}\right.$ of $\mathrm{ZnSO}_{4}$ in case of acid hydrolysis or $1 \mathrm{ml}$ of sodium sulfide in case of alkaline hydrolysis), 
Fig. 4 The main steps for chelated amino acid preparation from different wastes

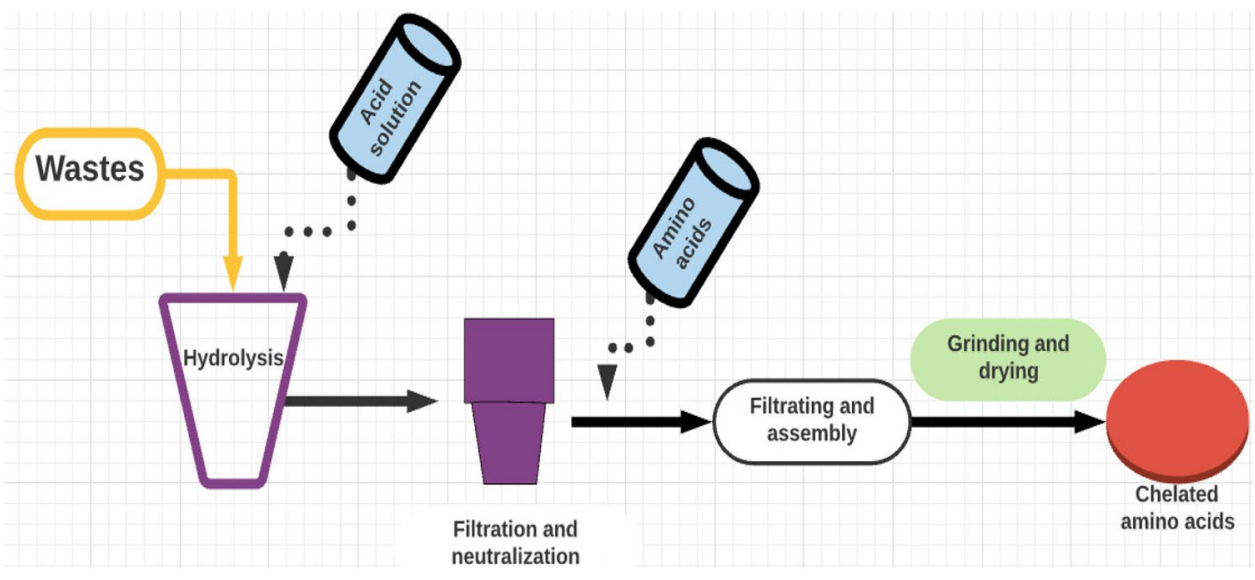

then heating in sand bath at $115-120{ }^{\circ} \mathrm{C}$ for 8 . Neutralization of the produced hydrolysate and filtration were followed by addition of sulfate salts of the minerals such as $\mathrm{CuSO}_{4} .5 \mathrm{H}_{2} \mathrm{O}, \mathrm{ZnSO}_{4} .7 \mathrm{H}_{2} \mathrm{O}, \mathrm{FeSO}_{4} .7 \mathrm{H}_{2} \mathrm{O}$, and $\mathrm{MnSO}_{4} \cdot 3 \mathrm{H}_{2} \mathrm{O}$ in ratio s $2: 1,2.5: 1$, and 3:1, in addition to $1 \%$ antioxidant. Mix well the hydrolysate and the sulfate salt and leave at room temperature until dry; wash and purify the formed solid by $95 \%$ ethanol as recommended by Jie et al. [8].

The second method used to prepare chelated minerals is to mix $2 \mathrm{mmol}$ of individual amino acids (such as histidine, arginine, or glycine) with $1 \mathrm{mmol}$ of zinc acetate (acetate salt of minerals) for several hours (more than 8) then dry and wash the formed crystals by cold ethanol and diethyl ether respectively (as reported by $[9,10]$.

The third method (modified method of Ghasemi et al. 2013) using $0.33 \mathrm{ml} / 20 \mathrm{ml}$ amino acid (leucine and methionine) at $\mathrm{pH} 8-10$ and chloride salts of the minerals instead of the acetate salts, stirring for minutes and washing the formed precipitate by water after filtration [11].

The fourth method for preparation of chelated organic synthesized fertilizer was performed from tomato and sugar beet thrones (as an agricultural waste) where the amino acids produced (from plant origin) were chelated with $\mathrm{Fe}, \mathrm{Zn}, \mathrm{Cu}, \mathrm{Mn}$, and B [12].

Application of these biofertilizers (as foliar spray or foliar spray plus added to the soil) or forage crops such as Pennisetum americanum and Sorghum vulgare. This fertilizer not only improved the growth and yield of the tested plants but also improved soil content of macro- and microelements as well as the organic matter.

Addition of half or one unit of NPK increased the efficiency of these commercially cheap source of chelated minerals-amino acids fertilizers especially when used in new poor sandy soil.

The followings are the main factors affecting mineral chelation:

\subsection{Time}

To optimize the chelation time, the chelation process was performed at constant conditions such as a molar ratio of $2: 1$, optimum $\mathrm{pH}$, and room temperature. However, use different times (20,40,60, and $80 \mathrm{~min}$, respectively). The obtained results by Jie et al. [8] revealed that all four times showed similar results.

\subsection{Ratio}

In order to reach the full utilization of amino acids and lead the high stability of product, Jie et al. [8] tried to find a suitable and optimum molar ratio between trace minerals and amino acids. During chelation process, trace mineral salts were mixed with amino acid hydrolysate product in different molar ratios. Data revealed that except 1:1 ratio, all other ratios (such as 2:1, 2.5:1, and 3:1) showed almost the same chelation rates.

\subsection{Temperature}

The chelation procedure was performed at different temperatures $20,40,60$, and $80^{\circ} \mathrm{C}$; the results obtained by Jie et al. [8] reported that all temperatures had a nonsignificant action on the rate of chelation.

\section{$2.4 \mathrm{pH}$}

The $\mathrm{pH}$ value affects the stability properties and structure of chelators [13]. Under high acidic conditions (low $\mathrm{pH})$, hydrogen proton competes with metal ions to get electron which is provided by electronic group in amino acids. Whereas under high alkaline conditions (high $\mathrm{pH}$ ), $\mathrm{OH}^{-}$competes with electronic group in amino acids to get metal ions, there will be more $\mathrm{OH}^{-}$deposit [14]. Both conditions hinder the chelation condition and product stability. 
Table 1 Suitable $\mathrm{pH}$ for each metal chelation

\begin{tabular}{ll}
\hline Metal & $\begin{array}{l}\text { Optimum pH (for } \\
\text { maximum chela- } \\
\text { tion) }\end{array}$ \\
\hline Iron & 5 \\
Copper & 7 \\
Zinc & 8 \\
Manganese & 4 \\
\hline
\end{tabular}

Sodium hydroxide and $\mathrm{HCl}$ were used to regulate solution $\mathrm{pH}$. At room temperature and a molar ratio 2:1, chelate synthesis was performed at $\mathrm{pH}$ ranged 4 to 10 . Data regarding the effect of $\mathrm{pH}$ on chelation rate (Table 1) revealed that $\mathrm{pH}$ significantly affected the rate of chelation of trace elements. Iron $(\mathrm{Fe})$ showed the highest rate of chelation around $\mathrm{pH} 5$ (97.3\%) and it gradually decreased as $\mathrm{pH}$ increased up to ten. Copper chelation rate was highest around $\mathrm{pH} 7$ (95.6\%) and it remained very high (>90\%) (Table 1).

\section{Nanoparticles of chelated amino acids, preparation and importance}

Yadav et al. [15] reported that Cds nanoparticles were synthesized using the amino acid histidine as organic chelating agent by sonochemical method. The imidazole ring of histidine captured the $\mathrm{Cd}^{++}$from the solution and prevents the growth of cds nanoparticles.

Preparation of cds nanoparticles (cds NPs) takes place by mixing $0.1 \mathrm{M} \mathrm{Cd}$-acetate with $0.1 \mathrm{M}$ sodium sulfide and $0.2 \mathrm{M}$ histidine as chelating agent (the mixture solution was $50 \mathrm{ml}$ ). The mixture solution was kept in sonochemical bath $(33 \mathrm{kHz}, 350 \mathrm{w})$ at room temperature for different ultrasonic irradiation times (30, 45, 90, and $135 \mathrm{~min})$. Centrifugation of the resulted yellow precipitate was achieved followed by washing with alcohol. To obtain the powdered cds nanoparticles, drying at $60{ }^{\circ} \mathrm{C}$ was necessary [16]. Set of experiments were performed by varying histidine conc. $(0.05,0.1,0.2 \mathrm{M})$, presence or absence of histidine, presence or absence of ultrasonic waves, and exposure times. These variations were to release the importance of these variables for cds NP formation. The obtained cds nanoparticles were characterized by XRD, UV-Vis spectrophotometer absorption, and TEM. The obtained results indicated the importance of histidine (at $0.2 \mathrm{M}$ ) and the ultrasonic irradiation (at $30 \mathrm{~min}$ ) in affecting the particle size $(1.4 \mathrm{~nm})$.

Zinc nanoparticles are among the most frequently used nanoparticles in agriculture. Green synthesis of $\mathrm{Zn}$-amino mono complexes, zinc-glutamate ( $\mathrm{Zn}$ - $\left.(\mathrm{Gly})_{2}\right)$, zinc glycine $\left(\mathrm{Zn}(\mathrm{Gly})_{2}\right)$, and zinc arginine $\left(\mathrm{Zn}(\mathrm{Arg})_{2}\right)$ were synthesized using ultrasonic irradiation and evaluated on the vegetative growth chemical composition and antioxidant activity of sweet basil compared with Zn-EDTA fertilizer. Greater vegetative growth and essential oil yield were obtained by using zinc-arginine nano complex with highest $\mathrm{Zn}$ concentration in shoots, elevating the conc. of major sesquiterpenes in sweet basil. Methanol-water (90-10 v/v) extract was analyzed by HPLC and rosmarinic acid was the predominant phenolic compound and $\mathrm{Zn}$-arginine nano complex significantly enhanced antioxidant activity of sweet basil. Foliar application of green synthesized $\left(\mathrm{Zn}-(\mathrm{Arg})_{2}\right)$ is recommended for $\mathrm{Zn}$ supplementation as well as for improving the pharmaceutical and nutritional values of the studied herb.

Nano-sized Zn-amino acid complexes were synthesized by dissolving $2 \mathrm{mmol}$ of amino acid (glutamine (Gln), glycine (Gly), and arginine (Arg) in $5 \mathrm{ml}$ of deionized distilled water. Mixed with $\mathrm{Zn}$ acetate solution, $\mathrm{Zn}(\mathrm{Aoc})_{2}$ of conc. $1 \mathrm{mmol}$ in $2 \mathrm{ml}$ dist. $\mathrm{H}_{2} \mathrm{O}$ and sonicated by ultrasonic. Dry the mixture under vacuum for $18 \mathrm{~h}$ to obtain dry dark brown powder (Tavallati et al., 2018). Characteristics of nanoparticles were achieved by TEM, EDX, and FTIR.

Iron $(\mathrm{Fe})$ is very important micronutrient that is involved in essential biochemical reactions such as cell growth, differentiation, gene regulation, electron transfer reactions, and oxygen transport. It is an important constituent of cytochrome, many enzymes, and heme group in hemoglobin [17].

Iron availability is greater in food of animal origin compared to plant origin (heme $15-35 \%$, non-heme $<10 \%$ respectively). Food fortification is a cost-effective intervention to combat iron deficiency and to provide the required amounts of micronutrients based on the recommended dietary allowance through foods. The most commonly iron salts used as food fortificants are ferrous sulfate, ferrous gluconate, and ferrous lactate to combat iron deficiency. Their limited bioavailability and high reactivity with other food components as well as their limited stability during processing and storage [18] led to the incorporation of novel nonsalt-based fortificants.

Recently iron-chelated peptides were suggested substituents of iron salts which improve the stability, absorption, and bioavailability of iron [19] and for fortification of food as bread with iron [20] and bouillon [21].

Whey protein-derived peptides (WPDP) were produced during the preparation of cow milk mozzarella cheese. Ultrafiltration to concentrate the protein content was performed according the method of Athira et al. [22]. The ultrafiltration residue was preheated at $70{ }^{\circ} \mathrm{C}$ for $10 \mathrm{~min}$, then hydrolyzed at $\mathrm{pH} 9$ and temp. $57^{\circ} \mathrm{C}$ for $8 \mathrm{~h}$ using alcalase enzyme with an enzyme-substrate mass ratio of 1:100. Denaturation of the enzyme (after hydrolysis) takes place by heating at $90{ }^{\circ} \mathrm{C}$ for $10 \mathrm{~min}$ cooled at room temp; then, remove the unhydrolyzed whey protein and enzyme by ultrafiltration using 10 KDa Mwt cut-off membrane. Micro Kjeldahl method [23] 
was used to estimate total protein content and determination of the degree of hydrolysis from alkali titration curve according to the method of Alder-Nissen [24].

The preparation of whey-derived peptide-Fe complex (WPDP-Fe) was done according to these steps: WPDP was mixed with $\mathrm{FeSO}_{4}$ at different mass ratios of protein and $\mathrm{Fe}$ (40:0.5/40:1/40:1.5/40:2) at temp. $40{ }^{\circ} \mathrm{C}$ for $2-4 \mathrm{~h}$ with continuous shaking. Adjust the $\mathrm{pH}$ of WPDP to different values (3, 5, and 7); then, mix with $\mathrm{FeSO}_{4}$ at ratio of $\mathrm{Fe}$ and protein $1: 40$.

Ferrozine assay [25] was performed to analyze the free iron content. WPDP-Fe complex was passed through different ultrafiltration membranes $(10,5,3 \mathrm{KDa}$ vivaspin 20 ultrafiltration spin column and centrifuged at $1300 \mathrm{~g}$ at $20^{\circ} \mathrm{C}$. Total $\mathrm{Fe}$, free $\mathrm{Fe}$, and protein content were estimated. WPDP-Fe complex was freeze dried and used for further characteristics.

The main characteristics of WPDP-Fe complex are peptides which are highly negatively charged. Involvement of acidic amino acids and their side chain carboxylic group for chelation.

The reduction in antioxidant activity of peptides showed the contribution of hydrophobic amino acids in the complex formation with $\mathrm{Fe}$. The key factors determining Fe-chelating ability are the net charge, size, functional groups of amino acids and peptides.

\subsection{Application and importance of WPDP-Fe complex}

Whey-derived peptide-Fe complex is considered a novel food-derived functional ingredient that can be used as a carrier of bioavailable $\mathrm{Fe}$ and as a potential alternative for chemical $\mathrm{Fe}$ fortificants for food products and $\mathrm{Fe}$ supplements.

Nowadays, there are serious concerns about the proper management of water resources especially in the countries facing water crisis. In the arid and semi-arid regions of the world, receiving much less rainfall than the plant requirement became a major challenge for subsequent decades [26].

Deficit irrigation is an important method used to reduce the irrigation water used and to cope with the water deficit crisis [27].

Wheat (Triticum aestivum L.) is one of the most important cereals which provides food for one-fifth of the world's population.

It is expected that the frequency and intensity of drought will be increased in the future due to climate change caused by the reduced rainfall and increase in evaporation due to global warming [28].

The use of nano fertilizers led to an increased crop productivity, reduction in the production cost, and reduction of biotic and abiotic stresses $[9,10]$.
The use of nano- $\mathrm{Zn}$ fertilizer plays an important role in the plant tolerance against the drought through increasing the lipids, protein, amino acids, and chlorophyll $\mathrm{b}$ content [29].

\subsection{Preparation of chelated nano fertilizer}

Boron, zinc, or silicon compounds were separately dissolved in some water using shaker; then add organic acid. After complete dissolution, initiator was added to start the nuclei generation. After 8-10 h, capping agent was added to stop the nuclei generation. Leave the solution for $6 \mathrm{~h}$ to be stabilized. Separate the nanoparticles by filtration; dry in an oven at $70{ }^{\circ} \mathrm{C}$.

Application of the nano fertilizer led to an improvement of wheat grain yield and increase in plant height, spike length, and No. of grains/spike and reduced the negative effects caused by deficit irrigation (50\% of irrigation requirement) by enhancing the SOD/CAT enzymes.

The best values were due to spraying by nano-silica fertilizer, followed by nano-boron and nano-zinc fertilizers which induced an increment in protein $\%$ of the wheat grain.

Spraying wheat plant by nano silica fertilizer led to reduction of the damage induced (or caused) by deficit irrigation and improvement of growth parameters of wheat plant [30].

About $40 \%$ of the global energy consumption were used in the building sector for heating, cooling, lighting, and ventilation.

An effective approach for reducing (minimizing) the energy required to heat or cool a building is the electro chromic windows.

If employ films using transition metal oxide as switchable glazing due to their thermal and chemical stabilities [31] and [32].

The coloration of the electro chromic (EC) oxide is induced by an electron transfer reaction accompanied by compensating transport of cations as $\mathrm{H}+, \mathrm{Li}+$ between EC oxide and electrolyte [33]. These EC oxides comprise metal-O-6-octahydra (hedra) in different corner sharing and edge-sharing arrangements [34]. Especially edge-sharing octahedra yield three-dimensional network of tunnels in the electrochromic oxides which sustain ionic transport in an electric field [34].

The EC oxides suffer from drawbacks of poor optical memory and low cycling stability which limit their potential commercialization [35]. So, EC oxides need an increased number of active sites and enhanced ion transport to increase the capacitive contribution during redox reaction of EC oxides. To achieve this, nanostructuring of the EC oxides is necessary.

Investigations indicated that films made from nanostructured EC oxides showed an exceptional EC performance compared to their bulk structures [36]. 
In case of NiO2 films, nano-sized deposit can be made from electrolytes containing Ni II-complexes with macrocyclic amine ligands [37].

Amino acid chelated complexes have been investigated as metal precursors for electrodeposition of nanostructured transition metal oxides due to their high buffering properties [38].

The samples prepared from mixed L-alanine and phenylalanine complexes show great improved EC performance.

\subsection{Sample preparation}

$\mathrm{Ni}\left(\mathrm{NO}_{3}\right)_{2} \cdot 6 \mathrm{H}_{2} \mathrm{O}$ and L-alanine (Ala) or phenylalanine (Phe) were added to potassium phosphate solution (prepared by a mixture of $\mathrm{K}_{2} \mathrm{HPO}_{4}$ and $\mathrm{K}_{2} \mathrm{PO}_{4}$ with a total $\mathrm{P}$ conc. of $0.1 \mathrm{M}$ at $\mathrm{pH}$ 11) to give a final $\mathrm{Ni}^{++}$conc. of $1 \mathrm{mM}$ and alanine conc. of $2 \mathrm{mM}$.

Alanine must be dissolved in pot. Phosphate before the addition of $\mathrm{Ni}(\mathrm{NO} 3) 2.6 \mathrm{H} 2 \mathrm{O}$ to avoid the precipitation of $\mathrm{Ni}(\mathrm{OH})_{2}$ from sol. $\mathrm{NiO}$ film was deposited on either the Ito glass or pt-pp film via controlled-potential electrolysis of $0.78 \mathrm{~V}$ (vs $\mathrm{Ag} / \mathrm{AgCl}$ ) from $\mathrm{Ni}^{++}$-containing pot. phosphate sol.

$\mathrm{UV}-\mathrm{Vis}$ absorption showed that $\mathrm{NiO}_{2}-\mathrm{Ala}$ and $\mathrm{NiO}_{2}-\mathrm{Phe}$ were deposited for 0.5 and $1 \mathrm{~h}$ with a broad peak around $40 \mathrm{~nm}$ indicating that nickel species were deposited on the Ito substrates. The peak intensity increases with time (peak intensity of $\mathrm{NiO}_{2}$-Ala is higher that of $\mathrm{NiO} 2-\mathrm{Phe}$ ). The molar ratios of L-alanine to phenylalanine were 4:1 (Mix-A4P1), 1:1 (Mix-A1P1), and 1:4 (Mix:A1P ${ }_{4}$ ).

$\mathrm{NiO}_{2}$-Ala had faster growth rate followed by the samples deposited from the mixed complexes and then $\mathrm{NiO}_{2}-\mathrm{Phe}$. $\mathrm{NiO}_{2}$-Ala has relatively smooth surface morphology consisted of closely packed gamma-NiOOH nanodeposits which give great improvement in the cycling stability and coloration efficiency (EC). While $\mathrm{NiO}_{2}$-Phe caused a low coloration efficiency and poor cycling stability, the aromatic side chains could passivate the sample surface, so improving the optical memory and they contributed to the charge transfer between the solid-liquid interface of the sample. These properties indicate that $\mathrm{NiO}_{2}$-Phe was a potential energy saving material for EC windows. The use of amino acid chelated complexes as metal precursors in electrodepositing of EC oxides shows great promise for EC window applications.

\section{Physical and chemical properties of chelated amino acids}

Microelement or metal ion binds to amino acids through the carboxyl group by one or more coordination covalent bonds forming a complex which have many functions (catalysis and nutrients) and applications in industry (animal and plant nutrition, pharmaceutical field).

The complex of metal chelated amino acids has specific properties which differ from the sulfate salt of the metal.

These properties depend on the metal ion and the ligand type (Abdel Rahman et al. 2017).

Metal ion complexes are stable at different $\mathrm{pH}$ values and high temperature. The amino acids protect the linked element from being affected by the environment and avoid the interaction with other chemical components [39].

Metal ion complex has wide applications in animal feeding, plant nutrition, and pharmaceutical field. The following are some other properties of chelated minerals:

\subsection{Testing of chelated minerals (CM)}

Simple test for verification of binding of organic mineral has not been available. There are varieties of tests which make subjective measurement of quality rather than chelation. The only method to verify that the product is an amino acid chelate is to look at the bonds that exist between the metal and the ligand. According to this FTIR technique is more useful to examine the product chelation.

The amino acids are existing as zwitterions in the crystalline state, and predominant vibrations for free amino acid ligands are associated with $\operatorname{vst}\left(-\mathrm{NH}_{2}\right), \operatorname{vst}(\mathrm{C}=\mathrm{O})$, vs $\left(-\mathrm{COO}^{-}\right)$, vst $(\mathrm{O}-\mathrm{H})$, and vst $(\mathrm{C}-\mathrm{N})$. In their complexes, the amino acids (AAs) generally act as bidentate ligands with respect to $\mathrm{pH}$; it binds with the metal by one oxygen and one nitrogen atom. Also, the noncoordinating groups $(\mathrm{C}=\mathrm{O})$ are hydrogen-bonded with the adjacent complex or with lattice water, as well as it forms weakly bonded with the metal containing neighboring complex. Thus, $v\left(-\mathrm{COO}^{-}\right)$of AA complexes are affected by each of coordination and intermolecular interactions. The major factor in determining the frequency order in AA complexes is the coordination effect. Our previous results indicate that the order of the metal-oxygen interaction increased because of the more asymmetrical of $-\mathrm{COO}^{-}$group and the metal-oxygen interaction becomes stronger. The FTIR spectra (Fig. 5) of three metal leather protein hydrolysate chelates showed an absorption pattern in the $4,000-400 \mathrm{~cm}^{-1}$ region similar to the region of AA. The predominant vibrations of the $\mathrm{Cu}^{++}$-LPHC, $\mathrm{Zn}^{++}$-LPHC, and $\mathrm{Fe}^{++}$-LPHC are associated with vst $(-\mathrm{NH} 2)$, vst $(\mathrm{C}=\mathrm{O})$, vs $\left(-\mathrm{COO}^{-}\right)$, vst $(\mathrm{O}-\mathrm{H})$, and ost $(\mathrm{C}-\mathrm{N})$. The vibration bands for $-\mathrm{OH}$ and $-\mathrm{NH}$ from 3300 to $3500 \mathrm{~cm}^{-1}$ (peak no. 1 in Fig. 2A, B, C, D and peak no. 2 in Fig. 5C) and the possibility of this vibration due to intermolecular hydrogen bond in polypeptides, histidine and arginine. The vibration band of $-\mathrm{NH}$ from 3130 to $3030 \mathrm{~cm}^{-1}$ and represented as peak No. 2 and 3, indicates the presence of free amino acids liberated from 
Fig. 5 FTIR spectral analysis of leather wastes $\mathrm{Cu}^{++}$-LPHC (A), $\mathrm{Zn}^{++}$-LPHC (B), and $\mathrm{Fe}^{++}$-LPHC (C) $[9,10]$

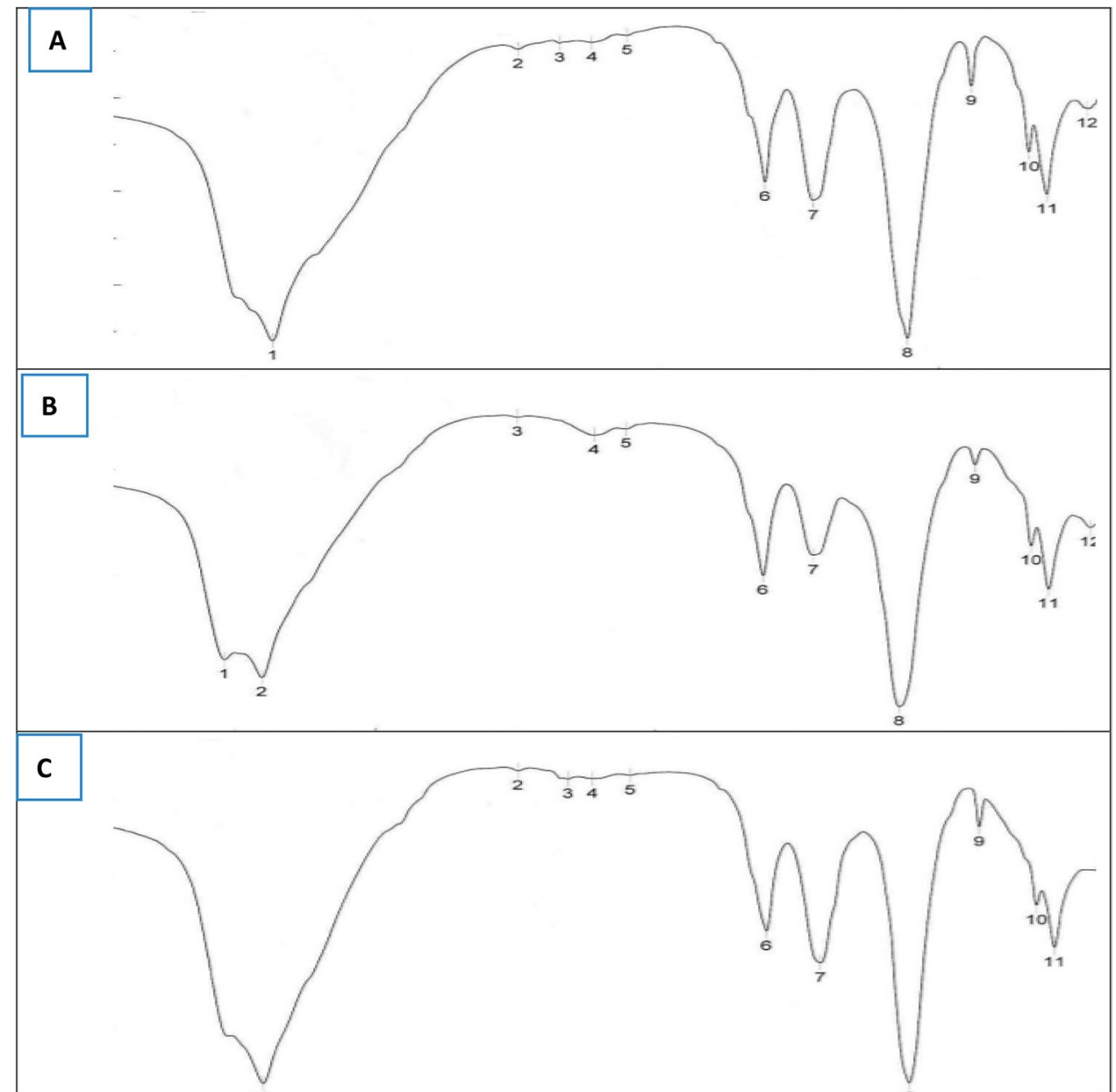

LPH (Fig. 5A). The stretching band of -NH in amino acid from 1660 to $1610 \mathrm{~cm}^{-1}$, peak No. 4 (Fig. 5A) and peak No. 6 (Fig. 5B, C, D). The vibration of $\mathrm{C}=\mathrm{O}$ from 1550 to $1610 \mathrm{~cm}^{-1}$, peak No. 5 (Fig. $5 \mathrm{~A}$ ) related to aspartic and glutamic acid, and $\delta \mathrm{CH}_{2}$ from 1470 to $1430 \mathrm{~cm}^{-1}$ in proline, peak No. 6 (Fig. 5A) and No. 7 (Fig. 5B, C, D) $[9,10]$.

\subsection{Molecular size determination of chelated minerals (CM)}

Molecular size clearly plays a role in the effectiveness of an organic mineral (OM) and provides a useful evaluation as to a product's potential efficacy. The protein-based OM is solubilized and then passed through a series of different size molecular filters. The molecular filter is used to evaluate the molecular size and the amount of each protein in the product. OMs passed through a 500 Dalton sieve filter are believed to be the best for highly absorption. Metal content is also assessed for each protein fraction to demonstrate the uniform bonding throughout the product.

\subsection{Test for solubility and structural integrity of $C M$}

The advantages in bioavailability of metals from chelated mineral supplements usually are attributed either to superior solubility or to the unique chemical structure of the product. The obtained results suggest that chelated minerals are highly soluble, yet chemically stable and electrically neutral in the digestive tract and that chelated minerals maintain their structural integrity in the digestive tract, arriving at the absorptive sites in the small intestine as an original intact molecule. Therefore, solubility test in simple buffers (acidic and alkaline $\mathrm{pH}$ ) and gel filtration chromatography to determine whether metals solubilized from the product are still complexed with amino acid or with other proteinous ligands, corroborated with free amino acid test using ninhydrin reagent parallel with metal determination [40].

\subsection{Ultraviolet (UV) spectroscopy}

The UV absorption spectra of metal ion and chelated metals are different; for example, the UV spectrum of calcium chloride, whey (WPH), and the whey-calcium chelate showed 


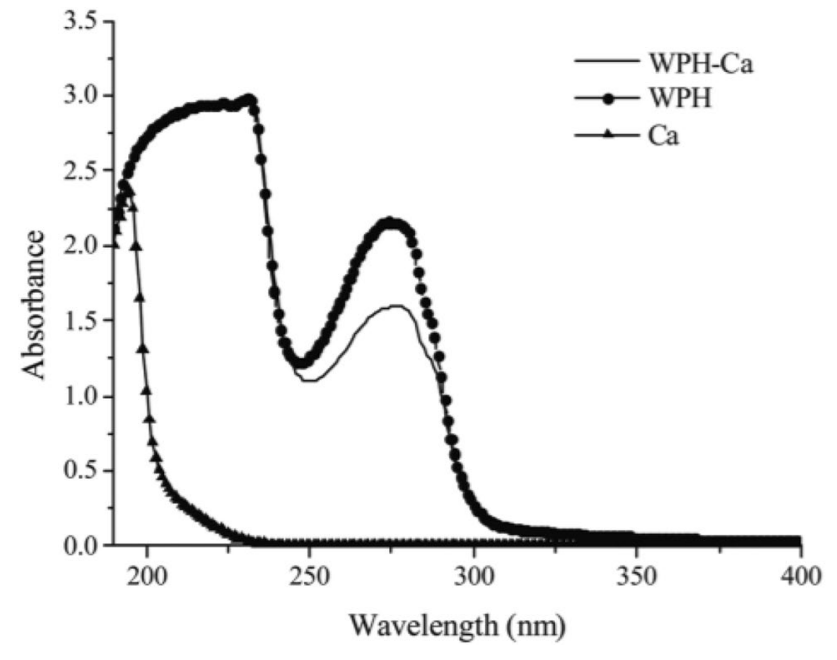

Fig. 6 UV spectra of WPH and the WPH-calcium chelate over a wavelength range from 190 to $400 \mathrm{~nm}$ [13]

obvious band shifts (Fig. 6). With the addition of calcium ions, the UV absorption spectra of whey were changed both in band and intensity in the area of 230 to $300 \mathrm{~nm}$. Also, The maximum absorption of whey shifted from 272 to $277 \mathrm{~nm}$, which meant that the oxygen atom of the carbonyl group in peptides was bonded with the calcium ions. Both the band shift and intensity changes suggest that whey could bind with calcium ions and therefore form a whey-calcium chelate [41].

\section{Applications of chelated amino acids}

\subsection{Animal nutrition}

Animals need several important microelements such as $\mathrm{Zn}$, $\mathrm{Cu}$, and $\mathrm{Fe}$. Each element has a vital role in the biological system (Fig. 2). For example, $\mathrm{Zn}$ is more essential in gene expression, immunity, and protein synthesis [42, 43]. It is required for enzymes as co-factor, bone formation, sexual maturity, hormone secretion, and normal growth of skeleton [44].

The bioavailability of microelements is low in the animal's intestine. Nanoparticles, in the contrary, are absorbed from gut and intestinal living cells then reached the blood and to different organs (Choi and Chey 2014).

Application of microelements in the form of nanoparticles will enhance the bioavailability due to the fact that nanoparticles decrease the antagonism during absorption and have a large surface area [45], Konkal and Wojnarowski, 2018,[9, 10].

Chelated micronutrients hold more stability than inorganic metals. So the absorbed amount from chelated minerals in the intestine of ruminant is more than the inorganic elements (Malik et al. 2017). Zn-methionine in ruminants minimizes the concentration of butyrate and increases that of propionate leading to the progress in ruminal microbes [46] and [39].

Supplementation of $\mathrm{Cr}$-glycinate in rat diet has a positive effect on diabetic rats where it decreases the glucose level and lipid profile parameters (total cholesterol, triglyceride, and HDL cholesterol level) as reported by Krol et al. (2019).

Feeding poultry with trace elements led to a marked decrease in early mortality of embryo and laying of eggs. Nano-zinc affects reproduction, feed conversion ratio, immunity, resistance of diseases (Salmonella and Campylobacter), blood level of antioxidant [47], fatty acids, and enzymes (SOD, catalase, and alkaline phosphatase) as reported by Hafez et al. [48].

Substitution of the inorganic ZnNPs led to a marked improvement in growth [49].

Feeding of broilers with organic sources of micronutrients such as $\mathrm{Cu}-\mathrm{Met}$ and $\mathrm{Cu}-\mathrm{Gly}$ has a positive effect on both productivity and blood parameters. They raise the conversion rate, increases the body weight, and enhances the immunity (due to elevation of $\operatorname{IgM}, \operatorname{IgG}$ ). In addition, it reduces liver enzymes, lipid profile (except HDL), and same kidney parameters (as creatinine) in the serum of treated broiler chicken especially at conc. $100 \mathrm{ppm}$ from each one [50].

Copper and zinc have several important functions for structural proteins such as keratin, collagen, and elastin in most times as skin, bone, connective time, claws, feathers, and cartilage (Leeson and Summer 2001, [51] as shown in Table 2.

Superoxide dismutase (SOD) is an essential enzyme to scavenge radical oxygen (ROS, reactive oxygen species). It is found in two places, one of them in cytoplasm, and it needs both $\mathrm{Zn}$ and $\mathrm{Cu}$. The second one is in the mitochondria which need manganese (Mn). If these required minerals are in less amounts than required, it causes an increase in lipid peroxidation and deterioration of DNA (Underwood and Shuttle 1999, [51, 52].

Paik [53] carried out series of experiments to evaluate the effect of chelated minerals (Met-Cu, Met-Zn, and Met-Fe) on the performance of pigs, chickens, and dairy cows. He reported that methionine copper chelates (Met$\mathrm{Cu}$ ) improved the weight gain and feed intake of both pigs and chickens at conc. (100-125 ppm) compared with copper sulfate $\left(\mathrm{CuSO}_{4}\right)$, while the conc. (75-100 ppm) of $\mathrm{Cu}$ laying performance and eggshell quality.

Methionine-zinc chelate (Met-Zn) was shown to be more effective than zinc oxide $(\mathrm{ZnO})$ in improving pig performance at conc. of 100-200 ppm.

Methionine-iron (Met-Fe) chelate was effective at $100 \mathrm{ppm}$ and increased the egg yolk by $20 \%$ within 15 days. He concluded that chelated minerals are effective in 
Table 2 Effect of different forms of chelated micronutrients in animal feeding

\begin{tabular}{|c|c|c|c|c|}
\hline Animal type & Element form & Dose & Effect of different forms & Reference \\
\hline \multirow[t]{2}{*}{ Broiler } & Nano zinc & $40,80,200 \mathrm{ppm}$ & $\begin{array}{l}\text {-Increased blood parameters and } \\
\text { serum lipid profile }\end{array}$ & Qi-You et al., 2007 \\
\hline & $\begin{array}{l}\text { Inorganic } \mathrm{ZnO} \text { and organic ( } \mathrm{Zn} \text { - } \\
\text { Gly) }\end{array}$ & $50 \mathrm{ppm}$ & •Increase finish weight & [44] \\
\hline \multirow[t]{3}{*}{ Ross 308 broilers } & $\begin{array}{l}\text { Inorganic and organic ( } \mathrm{ZnO} \text { and } \\
\mathrm{Zn-Gly)}\end{array}$ & $50 \mathrm{ppm}$ & $\begin{array}{l}\text {-Increase bone weight and length } \\
\text {-Increase ultimate strength of the } \\
\text { femur and tibia }\end{array}$ & \\
\hline & Organic (Zn-Gly) & $50 \mathrm{ppm}$ & $\begin{array}{l}\text {-Increase the level of IGF-1 in } \\
\text { serum } \\
\text { - Raise the level of copper and } \\
\text { phosphorus in serum } \\
\text {-Increase ultimate strength of } \\
\text { tibia }\end{array}$ & \\
\hline & & $100 \mathrm{ppm}$ & $\begin{array}{l}\text { - Raise the level of Zinc and iron } \\
\text { in serum }\end{array}$ & \\
\hline Broiler & Nano, organic and inorganic zinc & $50 \mathrm{pm}$ & $\begin{array}{l}\text {-Zinc methionine and nano } \\
\text { Zn successfully replaced the } \\
\text { inorganic source and increased } \\
\text { growth, antioxidant status, and } \\
\text { Zn retention }\end{array}$ & [49] \\
\hline \multirow[t]{2}{*}{ Laying chicken } & Nano, organic and inorganic zinc & 60 ppm & $\begin{array}{l}\text {-Enhance the absorption in the } \\
\text { intestines of aged hens }\end{array}$ & Tsai et al., 2016 \\
\hline & & $50,75,100 \mathrm{ppm}$ & $\begin{array}{l}\text { •Egg weight increased by nano- } \\
\text { Zn }(100 \mathrm{ppm}) \text {. Zn retention was } \\
\text { increased by supplementation } \\
\text { but not the source }\end{array}$ & Olgun and Yildiz, 2017 \\
\hline \multirow[t]{2}{*}{ Diabetic rats } & Cr-Gly & $10 \mathrm{mg} / \mathrm{kg} \operatorname{diet}(10 \mathrm{ppm})$ & $\begin{array}{l}\text {-Increase the body mass gain, } \\
\text { food efficiency ratio (FER) } \\
\text {-Decrease blood glucose and } \\
\text { insulin } \\
\text {-Decrease homeostasis model } \\
\text { assessment for insulin resistance } \\
\text { (HOMR-IR) } \\
\text {-Decrease urea level, creatinine, } \\
\text { triacylglycerols, total choles- } \\
\text { terol and thiobarbituric reactive } \\
\text { substance } \\
\text { - Raise iron level in liver tissue } \\
\text {-Decrease Cu level in liver and } \\
\text { heart tissue } \\
\text {-Decrease Cu/Zn ratio in spleen }\end{array}$ & Krol et al., 2020 \\
\hline & Cr-Gly and Cr-Picolinate & $10 \mathrm{mg} / \mathrm{kg} \operatorname{diet}(10 \mathrm{ppm})$ & $\begin{array}{l}\text {-Have the same effect on CRP } \\
\text { level }\end{array}$ & \\
\hline \multirow[t]{2}{*}{ Quail } & Nano Cr-picolinate & $200,400,600,800 \mathrm{ppb}$ & $\begin{array}{l}\text {-Increase the quality of eggs } \\
\text {-Enhance the absorption of } \mathrm{Ca}, \mathrm{Cr} \\
\text { and } \mathrm{P} \text { in liver }\end{array}$ & Amiri and Shahamat, 2015 \\
\hline & Nano zinc & $25,50,75$, and 100 & $\begin{array}{l}\text {-Improved weight gain and } \\
\text { weight of thigh and testes }\end{array}$ & Abbasi et al., 2017 \\
\hline Broiler chickens & $\mathrm{Cu}-\mathrm{Met}$ and $\mathrm{Cu}-\mathrm{Gly}$ & $50-100 \mathrm{ppm}$ & $\begin{array}{l}\text {-Increase RBCs, hemoglobin, } \\
\text { PCV and lymphocyte } \\
\text {-Increased the levels of globulin, } \\
\text { IgG, IgM, glucose, T3 and ALP } \\
\text { - Haven't significant on total } \\
\text { protein } \\
\text {-Decrease creatinine, MDA, AST, } \\
\text { ALT, abdominal fat and total } \\
\text { lipids except HDL } \\
\text { - Higher percentage of spleen }\end{array}$ & {$[50]$} \\
\hline
\end{tabular}


improving the performance of animals (pigs, chickens, and cows) at lower supplementary concentrations compared to inorganic minerals.

High levels of $\mathrm{CuSO}_{4}$ have been widely used as growthpromoting agent in pigs and broilers. Copper-polysaccharide complex at conc. of $62.5 \mathrm{ppm}$ of $\mathrm{Cu}$ was as effective as $200 \mathrm{ppm} \mathrm{Cu}$ in the form of $\mathrm{CuSO}_{4}$ in weaning pigs and broilers [54].

Also, the use of 2000-3000 ppm of $\mathrm{Zn}$ in the form of $\mathrm{ZnO}$ in weaning pig diet to improve its growth performance is known [55]. However, it was possible to achieve the same result by using 100-200 ppm of $\mathrm{Zn}$ in the form of Met- $\mathrm{Zn}$ [56].

Miles et al. [57] reported that $\mathrm{Cu}$ and $\mathrm{Mn}$ chelated amino acids should be acceptable as supplemental sources of $\mathrm{Cu}$ and $\mathrm{Mn}$ for inclusion in poultry diet and they may be less prone than their sulfate solutions to problems with caking in humid climates. Chloride salts of $\mathrm{Mg}, \mathrm{Ca}, \mathrm{Fe}, \mathrm{Co}, \mathrm{Cu}$, and $\mathrm{Zn}$ (100 $\mathrm{ml}$ of equi. molar quantities) have been reacted with amino acids (0.1 M DL-alanine, L-glutamic acid, and leucine) to synthesize metal chelated amino acids to be used as nutrient for both animals and plants because of their ease absorption.

National Research Council (NRC) in (1994) recommended the supplementation of corn-soybean diets with 40-40-7 mg/Kg Zn-Mn-Cu from organic source (metal amino acid complexes) to support performance of broiler chickens.

Zinc chelated amino acids (ZnAAs) may possess an advantage over classical $\mathrm{Zn}$ supplements (zinc salts), as they may be able to increase bioavailability of $\mathrm{Zn}$ and be more efficient in patients with acrodermatitis enteropathica (AE) as reported by Sauer et al. [58].

EDTA is widely used for treatment of seawater for rearing larvae of bivalves in aquaculture hatcheries. It improves the healthy status and growth parameters of the fish at concentration $0.3 \mathrm{~g} / \mathrm{L}$ [59].

It is used in chemical analysis, in medical applications as decontamination agents on radioactive surfaces and are ingredients in many commercial products as shampoos and food preservatives. It controls the heavy metal pollution in aquaculture and significantly decreases the level of minerals $(\mathrm{Ca}, \mathrm{Mg}, \mathrm{Fe}, \mathrm{Zn}, \mathrm{Mn}$, and $\mathrm{Cu})$ in the tissues of fishes (sequester metal ions).

\subsection{Plant nutrition}

Application of micronutrients to plants is mostly added to the soil or as foliar spray to plant leaves (Table 3). The inorganic mineral structures are hardly diffused from the leaf surface into plant, a cause of their high molecular weight structures $[5,60,61]$.

Chelation of amino acids to minerals and the formation of chelated minerals increased its availability compared to their inorganic sources and elevated efficiency of absorption and translocation of minerals within plants $[9,10]$.

Hydrolysate waste feather of chicken or leather waste was used as a commercial low-cost source for amino acids to which minerals $(\mathrm{Cu}, \mathrm{Zn}, \mathrm{Fe}, \mathrm{B}, \mathrm{Mn})$ were combined (using

Table 3 Effect of different forms of chelated micronutrients in plant nutrition

\begin{tabular}{|c|c|c|c|c|}
\hline Plant type & Element form & Dose & Effect of different forms & Reference \\
\hline $\begin{array}{l}\text { Chilli plants (Capsicum } \\
\text { annuum L.) }\end{array}$ & $\begin{array}{l}\text { Chelated } \mathrm{Zn}, \mathrm{Cu}, \mathrm{Fe} \text { and } \\
\mathrm{Mn}\end{array}$ & 1.5 and $2 \%$ & $\begin{array}{l}\text {-Increase the plant yield } \\
\text {-Improve the physiological } \\
\text { parameters of plant }\end{array}$ & Datir et al., 2012 \\
\hline $\begin{array}{l}\text { Marigold (Calendula } \\
\text { officinalis) }\end{array}$ & Aminochelate & $0.25 \%$ & $\begin{array}{l}\text {-Improvement of flowering } \\
\text { and postharvest life }\end{array}$ & Souri and Yarahmadi, 2016 \\
\hline Lisianthus cut flowers & $\begin{array}{l}\text { Ca-Lys, Ca-Thr and Ca- } \\
\text { Met }\end{array}$ & $0.1 \%$ & $\begin{array}{l}\text {-Increase the level of } \\
\text { IGF-1 in serum } \\
\text { - Raise the level of copper } \\
\text { and phosphorus in serum }\end{array}$ & Saeedi et al., 2015 \\
\hline Cotton & $\begin{array}{l}\text { Chelate zinc and nano } \\
\text { chelate zinc }\end{array}$ & - & $\begin{array}{l}\text {-Increase the total chlo- } \\
\text { rophyll } \\
\text {-Increase the dry weight } \\
\text {-Enhance the activity } \\
\text { of enzymes such as } \\
\text { peroxidase, catalase and } \\
\text { polyphenol oxidase } \\
\text {-Increase the number of } \\
\text { boll per plant }\end{array}$ & Rezaei and Abbasi, 2014 \\
\hline $\begin{array}{l}\text { Green bean (Phaseolus } \\
\text { vulgaris L.) }\end{array}$ & $\begin{array}{l}\text { Chelated amino acid } \\
\text { (glycine) }\end{array}$ & $\begin{array}{l}2.5 \% \mathrm{Zn}, 1.5 \% \mathrm{Mn}, 1 \% \mathrm{Fe}, \\
0.4 \% \mathrm{Mg}, 0.4 \% \mathrm{Cu} \text {, and } \\
0.02 \% \mathrm{Mo}\end{array}$ & $\begin{array}{l}\text { - Raise the number of plant } \\
\text { leaf and leaf area } \\
\text {-Increase TSS in pods }\end{array}$ & Aslani and Souri, 2018 \\
\hline
\end{tabular}


acidic or alkaline conditions) to form amino acid chelated mineral fertilizers.

Amino acid chelated $\mathrm{Zn}$ and $\mathrm{Fe}$ fertilizers and EDTA chelated $\mathrm{Zn}$ and $\mathrm{Fe}$ as well as zinc sulfate $\left(\mathrm{ZnSO}_{4}\right)$ and $\mathrm{FeSO}_{4}$ fertilizers were used as foliar application to rice plant.

The obtained results (Table 3) showed that $1 \%$ dilution of amino acid chelated $\mathrm{Zn}$ and Fe fertilizers induced a pronounced increase in growth parameters and yield from 22 to $73 \%$, while with EDTA chelated $\mathrm{Zn}$ and Fe the increase in growth was of 15-63\% and with inorganic salts fertilizers the increased parameters were only from 11 to $35 \%$ compared to control as reported by Jie et al. [8].

The use of chelated $\mathrm{Zn}$ and $\mathrm{Zn}$ oxide nanoparticles (ZnONPs) to Phaseolus vulgaris (L.) plant induced high plant productivity at different concentrations more than NPK application to soil. In ZnONP fertilizer, $25 \mathrm{ppm}$ (PonceGarcia et al. 2019) and conc. 0.1-0.15\% [62] were optimum concentrations for high plant productivity.

Application of more than one formula of $\mathrm{Zn}$ to cotton plant led to a remarkable increase in dry weight, plant height, chlorophyll a,b contents, and number of bolls/plant. Foliar application of amino acids chelated fertilizer improve the salinity and unbalanced nutrients in soil [63-65].

\section{Biological activities of metal chelated amino acids}

\subsection{Antimicrobial activity}

Ternary metal (II) complexes incorporate amino acid and imidazole derivatives were prepared and characterized using variable and different techniques $(\mathrm{Cu}, \mathrm{Co}, \mathrm{Ni}, \mathrm{Fe}$ with glutamine, glutaric, and glutamic acid (Co (glu) (IMI)2) and (Fe (glu) (IMI)2 (H2O2)) complexes. The compounds interact with DNA either by intercalative mode or by coordination mode leading to high MWt DNA complexes (DNA calenaues). Transition metal-based complexes have many potential practical applications as development of NA molecular probes and new therapeutic reagents for diseases. Metal II complexes showed good antibacterial activity.

The need to find antimicrobial active drugs increased with increasing multidrug-resistant microorganisms. The synthesized complexes have been evaluated for their antimicrobial efficiency against Pseudomonas aeruginosa and Bacillus cereus (Abdel-Rahman et al. 2017).

Abendrot et al. [66] reported that ZnAAs complex has an antibacterial effect against Staphylococcus aureus and E. coli compared to the standard antimicrobial drug zinc2-pyrrolidone-5-carboxylate (ZnPCA). Zn-Met and Zngly showed more efficiency than other amino acids. In the same context, Stanila et al. (2011) and Asemave et al. [67] recorded that $\mathrm{CuAAs}$ and Co-AAs complexes showed antibacterial effects against E. coli, Bacillus cereus, and Micrococcus luteus.

In addition, Fe-Leu complex demonstrated high effect than $\mathrm{Cu}-\mathrm{Leu}$ and their salts against Pseudomonas aerugi$n o s a$ and $E$. coli, while Cu-Leu chelate showed an effect on campylobacter than Fe-Leu as shown by Asemave et al. [67].

\subsection{Antioxidant activity}

It was known that derivatives of many amino acids have pronounced antioxidant activity and can inhibit development of tumor tissue in organism [68, 69]. However, there are no enough data or results related to the antioxidant activity of chelated amino acids and more studies are needed in the future.

\subsection{Antitumor and other biological activities}

Antitumor and antimetastatic and anti-inflammatory properties of amino acid derivatives have been detected [70].

Metal chelated amino acids are able to control many physiological processes occurring in cells and tissues of living organism, so changing the direction of proliferation and differentiation in many organs and generally leading to the enhancement of the immune protective abilities of the organism (Afanasev et al. 1995).

Leather protein hydrolysate with enzymes (Protease and Trypsin) or alkalis ( $\mathrm{KOH}$ and $\mathrm{CaO})$ showed to exhibit an antioxidant activity which is concentration dependent. Maximum scavenging activity was shown with protease hydrolysate followed in descending order by $\mathrm{KOH}$ hydrolysate, then trypsin and $\mathrm{CaO}$ respectively. The ability to scavenge free radicals corresponds to the content of amino acids and peptides in different hydrolysate as reported by Jacob et al. [71] and (2021).

\subsection{Dermatitis (skin treatment)}

Zinc ions $\left(\mathrm{Zn}^{++}\right)$were known to have dermatitis effects and are largely used in several products related to medical field as in antibacterial, antifungal, and anti-inflammatory application. Inorganic and organic zinc derivatives are currently used and new formula became necessary because of the bacterial resistance to old organic zinc derivatives (sulfate, nitrate, and chloride forms). Zinc sulfate causes skin irritation as side effects $[66,72]$.

Avoiding the presence of anions $\left(\mathrm{SO}^{2-}, \mathrm{NO}^{-}\right.$, and $\left.\mathrm{Cl}^{-}\right)$ in the required new zinc formula is necessary to be more secure as in case of $\mathrm{Zn}$-amino acid complex especially [66] which exhibits antibacterial effects. Also, zinc is used in cosmetics product in the form of zinc-ricinoleate which is considered anti-older agent as reported by Aquilina et al. [72]. 


\section{Conclusion}

It is concluded that animal and agriculture biomasses are a highly abundant renewable sources that can be transferred into various kinds of high-value-added products, including fertilizers and other advanced materials. Also, minerals from different organic sources (biomasses) have great bioavailability than inorganic sources. Diets supplemented with chelated minerals have greater mineral valorization or utilization than from inorganic sources. The enhancement mineral nutrition from the chelate supplements leads to improvement in production of milk, reproduction, and body condition compared with animals feed on inorganic sources.

In addition to ability to use the chelated amino acids with minerals as organic plant fertilizer, value may be of great significance to plant nutrition in cost reduction of nutrition and improving performance with high potential antioxidant and antimicrobial effects. Based on the findings, it was suggested that the minerals can be supplemented in combination of inorganic and organic sources at two-third and one-third levels of requirements, respectively, to obtain the maximum performance in animals and plant nutrition.

Funding Open access funding provided by The Science, Technology \& Innovation Funding Authority (STDF) in cooperation with The Egyptian Knowledge Bank (EKB).

Data availability The data used and analyzed in this study are available from the corresponding author on reasonable request.

\section{Declarations}

Ethics approval and consent to participate Not applicable.

Consent for publication Not applicable.

Competing interests The authors declare no competing interests.

Open Access This article is licensed under a Creative Commons Attribution 4.0 International License, which permits use, sharing, adaptation, distribution and reproduction in any medium or format, as long as you give appropriate credit to the original author(s) and the source, provide a link to the Creative Commons licence, and indicate if changes were made. The images or other third party material in this article are included in the article's Creative Commons licence, unless indicated otherwise in a credit line to the material. If material is not included in the article's Creative Commons licence and your intended use is not permitted by statutory regulation or exceeds the permitted use, you will need to obtain permission directly from the copyright holder. To view a copy of this licence, visit http://creativecommons.org/licenses/by/4.0/.

\section{References}

1. Ben-Iwo J, Manovic V, Longhurst P (2016) Biomass resources and biofuels potential for the production of transportation fuels in Nigeria. Renew Sustain Energy Rev 63:172-192

2. Paul R, Adzet JM, Brouta-Agnesa M, Balsells S, Esteve H (2012) Hydrolyzed collagen: a novel additive in cotton and leather dyeing. Dyes Pigm 94:475-480

3. Fela K, Wieczorek-Ciurowa K, Konopka M, Wozny Z (2011) Present and prospective leather industry waste disposal. Pol J Chem Technol 13(3):53-55

4. Mu C, Lin W, Zhang M, Zhu Q (2003) Towards zero discharge of chromium-containing leather waste through improved alkali hydrolysis. Waste Manage 23:835-843

5. Goos RJ, Johnson BE, Thiollet M (2000) A comparison of the availability of three zinc sources to maize (Zea mays L.) under greenhouse conditions. Biology and fertility of soils 31(3):343-347

6. Hsu HH (1986) Nutrient balance and crop yield, foliar feeding of plants with amino acid chelates. Albion Laboratories Inc., Clearfield, Utah, pp 183-198

7. Apines MJS, Satoh S, Kiron V, Watanabe T, Aoki T (2003) Availability of supplemental amino acid-chelated trace elements in diets containing tricalcium phosphate and phytate to rainbow trout. Oncorhynchus mykiss Aquaculture 225(1-4):431-444

8. Jie M, Raza W, Xu YC, Shen Q (2008) Preparation and optimization of amino acid chelated micronutrient fertilizer by hydrolyzation of chicken waste feathers and the effects on growth of rice. J Plant Nutr 31:571-582

9. Jacob, R.H; Hassan, H.M.M., Afify, A.S. and gaber, G. (2021). A novel synthesis chemical characterization and biological activities of metal-leather protein hydrolysate chelates. Fresenius Environmental Bulletin, 30- (07/2021): 8717-8727.

10. Jacob RH, Shanab SM, Shalaby EA (2021) Algal biomass nanoparticles: chemical characteristics, biological actions, and applications. Biomass Conv Bioref. https://doi.org/10.1007/ s13399-021-01930-y

11. Al-Jeboori FHA, Al-Shimiesawi TAM, Jassim OMN (2013) Synthesis and characterization of some essential amino acid metal complexes having biological activity. J Chem Pharm Res 5(10): $172-176$

12. Mostafa MA, Mubarak M, Khalil NS, Mohamad GH (2014) Manufacturing amino acids bio fertilizers from agricultural wastes. II-effect of synthetic organic fertilizers on the growth and yield of some forage crops as well as some soil properties. J Soil Sci and Agri Eng 5(2):279-294

13. Xixi C, Lina Z, Shaoyun W, Pingfan R (2015) Fabrication and characterization of the nanocomposite of whey protein hydrolysate chelated with calcium. Food Funct 6:816-823

14. Zhang HM, Chen GS, Yi MJ, Lu XH (2002) Study on chelate of complex amino acid with copper. Amino Acids Biotic Resources 24:37-40

15. Yadav RS, Mishra P, Mishra R, Kumar M, Pandey AC (2010) Growth mechanism and optical property of CdS nanoparticles synthesized using amino-acid histidine as chelating agent under sonochemical process. Ultrason Sonochem 17(1):116-122

16. Wang KH, Ikeuchi H, Yoshida M, Tsunekawa S, Liu I, Cui S, Kawai T (2021) Insights into the deposition of nanostructured nickel oxides by amino acid chelated complexes: benefits of mixed side chains in the formation of nanostructures for Energyefficient Electrochromic windows. Appl Surface Sci 568:150914

17. Gkouvatsos K, Papanikolaou G, Pantopoulos K (2012) Regulation of iron transport and the role of transferrin. Biochimica et Biophysica Acta (BBA)-General Subjects 1820(3):188-202 
18. Von Grebmer, K., Saltzman, A., Birol, E., Wiesman, D., Prasai, N., Yin, S., Sonntag, A. (2014). Synopsis: 2014 Global hunger index: the challenge of hidden hunger. Intl Food Policy Res Inst, 83.

19. Li Y, Jiang H, Huang G (2017) Protein hydrolysates as promoters of non-haem iron absorption. Nutrients 9(6):609

20. Takeda T, Carvalho Vila MMD, Sant Ana LL, Severino P, Chaud MV (2016) Development of fortified bread using peptide-iron chelate: A perspective to prevent iron deficiency anemia. Journal of Public Health Aspects 3(1):1

21. Gupta S, Habeych E, Scheers N, Merinat S, Rey B, Galaffu N, Sandberg AS (2020) The development of a novel ferric phytate compound for iron fortification of bouillons (part I). Sci Rep 10(1):1-10

22. Athira S, Mann B, Saini P, Sharma R, Kumar R, Singh AK (2015) Production and characterisation of whey protein hydrolysate having antioxidant activity from cheese whey. J Sci Food Agric 95(14):2908-2915

23. AOAC (2005) Official methods of analysis. The association of official analytical chemists, 18th edn. North Fredrick Avenue Gaithersburg, Maryland, USA

24. Alder-Nissen, J. (1986). Enzymatic hydrolysis of food proteins. Elsevier Applied science publishers.

25. Wu H, Liu Z, Zhao Y, Zeng M (2012) Enzymatic preparation and characterization of iron-chelating peptides from anchovy (Engraulis japonicus) muscle protein. Food Res Int 48(2):435-441

26. Geerts S, Raes D (2009) Deficit irrigation as an on-farm strategy to maximize crop water productivity in dry areas. Agric Water Manag 96(9):1275-1284

27. Fereres E, Soriano MA (2007) Deficit irrigation for reducing agricultural water use. J Exp Bot 58(2):147-159

28. Dai A (2011) Drought under global warming: a review. Wiley Interdisciplinary Reviews: Climate Change 2(1):45-65

29. Sedghi M, Hadi M, Toluie SG (2013) Effect of nano zinc oxide on the germination parameters of soybean seeds under drought stress. Annales of West University of Timisoara Series of Biology 16(2):73

30. Ahmadian K, Jalilian J, Pirzad A (2021) Nano-fertilizers improved drought tolerance in wheat under deficit irrigation. Agricultural Water Management 244:106544

31. Cai G, Wang J, Lee PS (2016) Next-generation multifunctional electrochromic devices. Acc Chem Res 49(8):1469-1476

32. Yang P, Sun P, Mai W (2016) Electrochromic energy storage devices Materials today 19(7):394-402

33. Patel KJ, Bhatt GG, Ray JR, Suryavanshi P, Panchal CJ (2017) All-inorganic solid-state electrochromic devices: a review. J Solid State Electrochem 21(2):337-347

34. Cong S, Geng F, Zhao Z (2016) Tungsten oxide materials for optoelectronic applications. Adv Mater 28(47):10518-10528

35. Chen PW, Chang CT, Ko TF, Hsu SC, Li KD, Wu JY (2020) Fast response of complementary electrochromic device based on WO 3/NiO electrodes. Sci Rep 10(1):1-12

36. Yang H, Yu JH, Seo HJ, Jeong RH, Boo JH (2018) Improved electrochromic properties of nanoporous $\mathrm{NiO}$ film by $\mathrm{NiO}$ flake with thickness controlled by aluminum. Appl Surf Sci 461:88-92

37. Singh A, Chang SL, Hocking RK, Bach U, Spiccia L (2013) Anodic deposition of $\mathrm{NiO} \times$ water oxidation catalysts from macrocyclic nickel (ii) complexes. Catal Sci Technol 3(7):1725-1732

38. Tooley CA, Gasperoni CH, Marnoto S, Halpern JM (2018) Evaluation of metal oxide surface catalysts for the electrochemical activation of amino acids. Sensors 18(9):3144

39. Malik TA, Mir SH, Pal RP (2017) Review of chelated versus inorganic zinc supplementation in ruminants. Nutri Food Sci Int J 4(2):1-3
40. Brown TF, Zeringue LK (1994) Laboratories evaluation of solubility and structural integrity of complexed and chelated trace mineral supplements. J Dairy Sci 77:181-189

41. Armas A, Sonois V, Mothes E, Zazarguil H, Faller P (2006) J Inorg Biochem 100:1672-1678

42. Cao J, Henry PR, Davis SR, Cousins RJ, Miles RD, Littell RC, Ammerman CB (2002) Relative bioavailability of organic zinc sources based on tissue zinc and metallothionein in chickens fed conventional dietary zinc concentrations. Anim Feed Sci Technol 101:161-170

43. Park SY, Birkhold SG, Kubena LF, Nisbet DJ, Ricke SC (2004) Review on the role of dietary zinc in poultry nutrition, immunity, and reproduction. Biological Trace Elements Research 101:147-163

44. Tomaszewska E, Muszyński S, Dobrowolski P, Kwiecień M, Winiarska-Mieczan A, Świetlicka I, Wawrzyniak AV (2017) Effect of zinc level and source (zinc oxide vs. zinc glycine) on bone mechanical and geometric parameters, and histomorphology in male Ross 308 broiler chicken. Brazilian Journal of Poultry Science 19(1):159-170

45. Zaboli K, Aliarabi H, Bahari AA, Abbasalipourkabir R (2013) Role of dietary nano-zinc oxide on growth, performance and blood levels of mineral: a study on Iranian Angora (markhoz) goat kids. International Advisory Board 2(1):19-26

46. Arelovich HM, Amela MI, Martínez MF, Bravo RD, Torrea MB (2014) Influence of different sources of zinc and protein supplementation on digestion and rumen fermentation parameters in sheep consuming low-quality hay. Small Rumin Res 121(2-3):175-182

47. Lina T, Fenghua Z, Huiying R, Jianyang J, Wenli L (2009) Effects of nano-zinc oxide on antioxidant function in broilers. Chin J Anim Nutr 21(4):534-539

48. Hafez A, Nassef E, Fahmy M, Elsabagh M, Bakr A, Hegazi E (2019) Impact of dietary nano-zinc oxide on immune response and antioxidant defense of broiler chickens. Environ Sci Pollut Res. https://doi.org/10.1007/s11356-019-04344-6

49. Ibrahim D, Ali HA, El-Mandrawy SAM (2017) Effects of different zinc sources on performance, bio distribution of minerals and expression of genes related to metabolism of broiler chickens. Zagazig Vet J 45(3):292-304

50. El-Ghalid OAH, El Ashry GM, Soliman SM, Abd EL-Hady, A.M. (2019) Effect of dietary sources and levels of copper supplementation on growth performance, blood parameters and slaughter traits of broiler chickens. Egypt Poult Sci 39(4):897-912

51. Richards JD, Zhao J, Harrell RJ, Atwell CA, Dibner JJ (2010) Trace mineral nutrition in poultry and swine. Asian Australas J Anim Sci 23(11):1527-1534

52. Kokoszka JE, Coskun P, Esposito LA, Wallace DC (2001) Increased mitochondrial oxidative stress in the Sod2 (+/-) mouse results in the age-related decline of mitochondrial function culminating in increased apoptosis. Proc. Natl. Acad. Sci. USA 98:2278-2283

53. Paik IK (2001) Application of chelated minerals in animal production. Asian-Australasian Journal of Animal Science 14:191-198

54. Paik IK, Kim YK (1993) The effects of supplemental sources of copper on the performance of weanling pigs and broilers. In Proceedings of VII World Conference on Animal Production, Edmonton, Alberta, Canada 2:395-393

55. Thacker, P. A. (2000). Nutritional requirements of early weaned pigs proceedings. Korea-Canada Seminar on pig production Technology. Korean Agricultural Cooperation. 87-113.

56. Ahn SH, Um JS, Kim DH, Paik IK (1998) Effects of the sources and levels of supplemental zinc on the performance of weanling pigs. Korean Journal of Animal Science 40(1):9-20 
57. Miles RD, Henry PR, Sampath VC, Shivazad M, Comer CW (2003) Relative bioavailability of novel amino acid chelates of manganese and copper for chicks. J Appl Poultry Res 12(4):417-423

58. Sauer AK, Pfaender S, Hagmeyer S, Tarana L, Mattes AK, Briel F, Grabrucker AM (2017) Characterization of zinc amino acid complexes for zinc delivery in vitro using Caco-2 cells and enterocytes from hiPSC. Biometals 30(5):643-661

59. Nicula M, Gergen I, Harmanescu M, Banatean-Dunea I, Marcu A, Simiz E, Lunca M (2011) Assessing the impact of EDTA chelating effect on some macro-and microminerals in Prussian carp (Carassius gibelio) tissues. Scientific Papers Animal Science and Biotechnologies 44(2):40-44

60. Ahmed, Y.M.; Shalaby, E.A.; Shanan, N.T. The use of organic and inorganic cultures in improving vegetative growth, yield characters and antioxidant activity of roselle plants (Hibiscus sabdariffa L.). Afr. J. Biotechnol. 2011, 10, 1988-1996.

61. Elakbawy WM, Shanab SMM, Shalaby EA et al (2021) Plant growth regulators from microalgae biomass and their impact on the genetic fidelity of canola and tomato plantlets. Biomass Conv Bioref. https://doi.org/10.1007/s13399-021-02097-2

62. Mahdieh, M.; Sangi, M.R.; Bamdad, F. and Ghanem, A. (2018). Effect of seed and foliar application of nano-zinc oxide, zinc chelate, and zinc sulphate rates on yield and growth of pinto bean (Phaseolus vulgaris) cultivars. Journal of Plant Nutrition, 1-12.

63. Ghasemi S, Khoshgoftarmanesh AH, Afyuni M (2014) Iron (II)amino acid chelates alleviate salt-stress induced oxidative damages on tomato grown in nutrient solution culture. Scientia Hort 165:91-98

64. Sadak M, Abdoelhamid MT, Schmidhalter U (2015) Effect of foliar application of aminoacids on plant yield and some physiological parameters in bean plants irrigated with sea water. Acta Biol Colomb 20(1):141-152

65. Souri MK, Aslani M (2018) Beneficial effects of foliar application of organic chelate fertilizers on French bean production under field conditions in a calcareous soil. Adv Hort Sci 32(2):265-272

66. Abendrot, M.; Ch cei 'nska, L.; Kusz, J.; Lisowska, K.; Zawadzka, K.; Felczak, A. and Kalinowska-Lis, U. (2020). Zinc (II) Complexes with amino acids for potential use in dermatology: synthesis, crystal structures, and antibacterial activity molecules, 25 , 951.

67. Asemave K, Anhwange BA, Anom TJ (2013) Antibacterial studies of leucine complexes of $\mathrm{Fe}$ (III) and $\mathrm{Cu}$ (II). International Journal of Science and Research 4(1):1527-1529

68. Abou Elalla FM, Shalaby EA (2009) Antioxidant activity of extract and semi- purified fractions of marine red macroalga, Gracilaria Verrucosa. Aust J Basic Appl Sci 3(4):3179-3185

69. Khasina AG, Copala J, Probhakeu IW (1998) Antioxidant efficacy of amino acids in methyl linoleate of different relative humidities. IAm Oil Chem Soc 71(6):645-647

70. Sorenson, J. R. J. (1998). Copper complexes for therapy of cancer and autoimmune diseases. In Copper and Zinc in Inflammatory and Degenerative Diseases (pp. 113-124). Springer, Dordrecht.

71. Jacob RH, Hassan HMM, Afify AS (2016) Evaluation of antioxidant and metal chelating activities of protein hydrolysates produced from leather waste by alkaline and enzymatic hydrolysis. Res J Pharm, Biol Chem Sci 7(4):910-919

72. Aquilina G, Bach A, Bampidis V, De Lourdes Bastos M, Flachowsky G, Gasa-Gasó J, Gralak MA, Hogstrand C, Leng L, López-Puente S, Martelli G, Mayo B, Renshaw D, Rychen G, Saarela M, Sejrsen K, Van Beelen P, Wallace RJ, Westendorf J (2012) Scientific Opinion on the safety and efficacy of niacin (nicotinic acid and nicotinamide) as a feed additive for all animal species based on a dossier submitted by VITAC EEIG. EFSA J 10(10):2885

73. Abdel-Rahmana LH, Abu-Diefa AM, Ismaila NM, Ismaela M (2017) Synthesis, characterization, and biological activity of new mixed ligand transition metal complexes of glutamine, glutaric, and glutamic acid with nitrogen-based ligands. Inorganic and Nano-Metal Chemistry 47(3):467-480

74. Afanas' ev, I. B., Suslova, T. B., Cheremisina, Z. P., Abramova, N. E., Korkina, L. G. (1995) Study of antioxidant properties of metal aspartates. Analyst 120(3):859-862

75. Athira S, Mann B, Sharma R, Pothuraju R, Bajaj RK (2021) Preparation and characterization of iron-chelating peptides from whey protein: an alternative approach for chemical iron fortification. Food Research International 141:110133

76. Choi S, Choy J (2014) Biokinetics of zinc oxide nanoparticles: toxicokinetics, biological fates, and protein interaction. Int J Nanomedicine 9(2):261-269

77. Konkol D, Wojnarowski K (2018) Review of the use of nanominerals in animal nutrition as a way to improve the composition and quality of animal products. J Chem. https://doi.org/10.1155/2018/ 5927058

78. Król E, Krejpcio Z, Okulicz M, Śmigielska H (2019) Chromium (III) glycinate complex supplementation improves the blood glucose level and attenuates the tissular copper to zinc ratio in rats with mild hyperglycaemia. Biol Trace Elem Res 193:185-194

79. Leeson S, Summers JD (2001) Scott's nutrition of the chicken, 4th edn. University Books, Guelph, Ontario

80. Mahdi HH, Mutlag LA, Mouhamad RS (2019) Study the effect of khazra iron nano chelate fertilizer foliar application on two rapeseed varieties. Rev Bionatura 4:841-845

81. Motazedian A, Kazemeini SA, Bahrani MJ (2019) Sweet corn growth and GrainYield as influenced by irrigation and wheat residue management. Agric Water Manag 224:1-9

82. National Research Council. (1994). Nutrient requirements of poultry. 9th Revised edn. National Academies Press. Washington D C.

83. Ponce-García CO, Soto-Parra JM, Sánchez E, Muñoz-Márquez E, Piña-Ramírez FJ, Flores-Córdova MA, Pérez-Leal R, Muñoz RMY (2019) Efficiency of nanoparticle, sulfate, and zinc-chelate use on biomass, yield, and nitrogen assimilation in green beans. Agronomy 9:128

84. Qadir MA, Ahmed M, Ahmad A, Naz S, Tirmazi SAAS, Khan R, Waseem R (2014) Synthesis of metal complexes with amino acids for animal nutrition. Glob Vet 12:858-861

85. Shanab, S.M.M., Hanafy, E.A. \& Shalaby, E.A. Water hyacinth as non-edible source for biofuel production. Waste Biomass Valor 9, 255-264.

86. Stănilă A, Braicu C, Stănilă S, Pop RM (2011) Antibacterial activity of copper and cobalt amino acids complexes. Not Bot Horti Agrobo 39(2):124-129

87. Suttle FN (2010) Mineral nutrition of livestock. CAB International, Cambridge, USA

88. Tavallali V, Rowshan V, Bahmanzadegan A (2018) Variations in sweet basil in response to Green synthesized Zinc-Amino nano complexes. J Clean Prod 196:452-459

89. Underwood EJ, Suttle NF (1999) The mineral nutrition of livestock, 3rd edn. CABI Publishing, New York

Publisher's note Springer Nature remains neutral with regard to jurisdictional claims in published maps and institutional affiliations. 